\title{
Active battery balancing system for electric vehicles based on cell charger
}

\author{
Amin, Alexander Christantho Budiman, Sunarto Kaleg, Sudirja, Abdul Hapid \\ Electric Vehicle Research Group, Research Centre for Electrical Power and Mechatronics, Indonesian Institute of \\ Sciences (LIPI), Bandung, Indonesia
}

\begin{tabular}{l} 
Article Info \\
\hline Article history: \\
Received Oct 16, 2020 \\
Revised Jan 27, 2021 \\
Accepted Feb 9, 2021 \\
\hline
\end{tabular}

Keywords:

Active balancing

Battery balancing

Battery equalization

Battery management system

Electric vehicles

\begin{abstract}
Cell imbalance can cause negative effects such as early stopping of the battery charging and discharging process which can reduce its capacity. In the previous active balancing research, the energy used for the balancing process was taken from the cell or battery pack, resulting in drop of electric vehicle driving range. In this paper, a cell charger based battery balancing system is proposed with a reduction in the number of switches. The use of a cell charger aims to increase the usable energy of the battery pack, since the energy used for the balancing process is taken directly from the grid. The use of fewer switches aims to reduce the cost and space used on the battery management system (BMS) hardware. The charger used for the balancing process has a maximum current of $3 \mathrm{~A}$ and a maximum voltage of $3.65 \mathrm{~V}$ while the number of switches used is $n+5$ for $n$ batteries. A 15S1P $200 \mathrm{Ah}$ $\mathrm{LiFePO} 4$ battery pack consists of 15 cells used for testing purpose. The test results show that the time needed to equalize the 15 cell battery voltage reaches 6 hours from the difference between the highest and lowest battery cell voltages of $145.1 \mathrm{mV}$ to $15.1 \mathrm{mV}$.
\end{abstract}

This is an open access article under the CC BY-SA license.

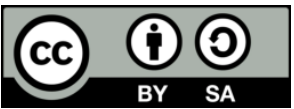

\section{Corresponding Author:}

Amin

Electric Vehicle Research Group, Research Centre for Electrical Power and Mechatronics

Indonesian Institute of Sciences (LIPI)

J1. Sangkuriang 21, Building 60, Bandung, West Java 40135, Indonesia

Email: amin@lipi.go.id

\section{INTRODUCTION}

In the electric vehicle application, a battery cell needs to be connected in series or series-parallel to step up their voltage and capacity to support the system requirements. In the battery pack, all batteries are not made perfectly the same. Even if the batteries show the same chemistry with the same shape, weight, and physical size, there could still be minor differences in terms of total capacities, internal resistances, self discharge, or different aging which would directly influence the overall battery life [1].

Even with a careful battery cell selection, small differences in battery cell capacity cannot be completely avoided. Therefore, whenever the battery is being charged or discharged, there will be a small imbalance in the State of Charge (SoC) between individual cells. Battery pack imbalance can cause negative impacts such as early stopping of the charging process and discharging the battery which can reduce the usable energy [2]. To prevent this problem, charge equalization or cell balancing methods would be applied by means of the battery management system (BMS) [3].

To date, various cell balancing methods have been studied, with the purpose of reducing the battery voltage imbalance. These methods can generally be classified into two categories so called passive and active methods. Passive balancing method involves dissipating energy from battery cells that have a higher voltage, 
thereby equalizing all cell voltage levels in the battery pack with the lowest cell voltage. Although this method offers good balancing performance, low cost and is quite simple to implement [4], it does have two main weaknesses. Firstly, such method usually creates unwanted side effects with regards to its thermal management system. As such, the battery pack might require an addition of thermal protection which increases the overall weight of the system. Secondly, the energy saving objectives are not maximized due to energy loss during balancing.

In contrast to an inefficient passive method above, the active battery balancing will transfer energy from the stronger cell/module to the weaker cell/module using a variety of balancing methods such as capacitor-based active balancing [5-8], inductor/transformer-based active balancing [9-14], and converterbased active balancing [15-19]. The active and passive balancing methods for lithium-based batteries have also been studied thoroughly in [1], [20-24]. In addition, a comparison between different balancing methods has been reported by [23-28], where the balancing methodology is classified depending on the number of switches, transformers, capacitors, inductors, diodes, modularity, complexity, reliability, cost, and so on.

In the previous active balancing research, the energy used for the balancing process was taken from the cell or battery pack. The major disadvantage of such active balancing systems is the reduced use of energy from the battery pack which results in reduced mileage of electric vehicles. Ideally, the solution to maximize the efficiency and control the energy loss problems in the conventional battery balancing methods is to use an external energy source to charge cells with low SoCs [29]. The use of energy from external sources to charge or balance the cells/modules that have low SoC has been used in previous studies, namely using solar power [29], auxiliary power module [30], and redundant battery [31]. In [31], redundant battery is used to balance three lithium-ion batteries in series with a small capacity of $1800 \mathrm{mAh}$ and $1000 \mathrm{mAh}$ while in [29], solar power is used to balance four $100 \mathrm{Ah}$ lead acid batteries. In these previous papers, $2 n$ switches are used for $n$ batteries where on [29], each switch uses 2 dc solid state relays while in [31], it uses general purpose relays. In [30], the auxiliary power module is used to balance five NCR 18650 batteries with a capacity of $6 \mathrm{Ah}$ and requires a balancing time of 10.7 to 22.2 minutes with several control methods to achieve a SoC difference of $1 \%$.

The use of many large capacity batteries in a serial connection is very rarely found in the literature. In [32], 13 lithium-ion cells are connected in series with a capacity of $10 \mathrm{Ah}$. The LC circuit is used to balance cells using $2 n$ switches, where each switch uses two MOSFETs connected in series. The time needed to balance the voltage reached 6 hours from the difference between the highest and lowest cell voltages of $460 \mathrm{mV}$ to $336 \mathrm{mV}$. Different from the previous study, in this paper, battery balancing system based on cell charger is proposed. Compared with the use of energy storage systems (ESS) and energy harvesting system (EHS) in previous studies [29]-[31], the use of a cell charger that draws energy directly from the grid can reduce the cost of replacing ESS and EHS which have a life time. In addition, the absence of ESS and EHS reduces the space required if the battery pack is used for electric vehicles. This paper also proposes the use of fewer switches to reduce costs and space on the BMS hardware. The proposed balancing method would be validated experimentally using 15 large-capacity $\mathrm{LiFePO}_{4}$ batteries with a capacity of $200 \mathrm{Ah}$.

\section{BALANCING METHODS}

The block diagram of the proposed active BMS is shown in Figure 1. The voltage of the 15 cells is monitored by an ATtiny45V microcontroller to protect them from any possible overcharge and undercharge conditions. The voltage is monitored via a solid-state relay (SSR) associated with the cell which is regulated by the main microcontroller (ATmega2560) via signal conditioning circuit. The results of the cell voltage reading will be processed by the main microcontroller to regulate the pack charger and cell charger.

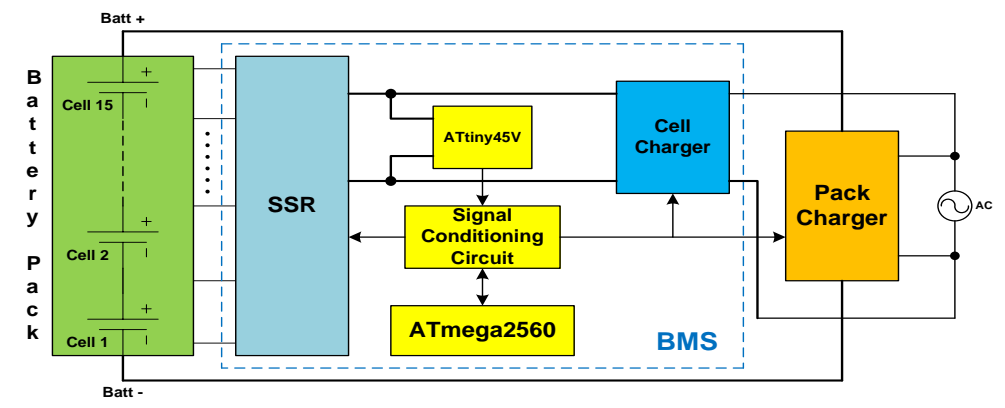

Figure 1. The proposed active BMS block diagram 
The working concept of the circuit in Figure 1 is to read the voltage through the ATtiny45V microcontroller ADC and output an analog voltage signal (PWM) through the optocoupler in the signal conditioning circuit so that isolation occurs between the cell voltage and the main microcontroller voltage. The ATtiny45V microcontroller power supply comes from the battery cell voltage.

\subsection{SSR circuit design}

To monitor the condition of each cell in the battery pack, an SSR circuit with a certain configuration is needed as displayed in Figure 2. The SSR circuit design also aims to determine the specific cell that will be balanced by the cell charger. In this study, the SSR used is $60 \mathrm{~V}$ single-pole, normally open power relay with a current capability of 6.5 A without heat sink. The use of this SSR is based on considerations of durability compared to mechanical relays which still use mechanical contacts in their operation. In addition, the use of SSR is based on its ability to switch between the on and off conditions quickly, and the absence of sparks at its point of contact.

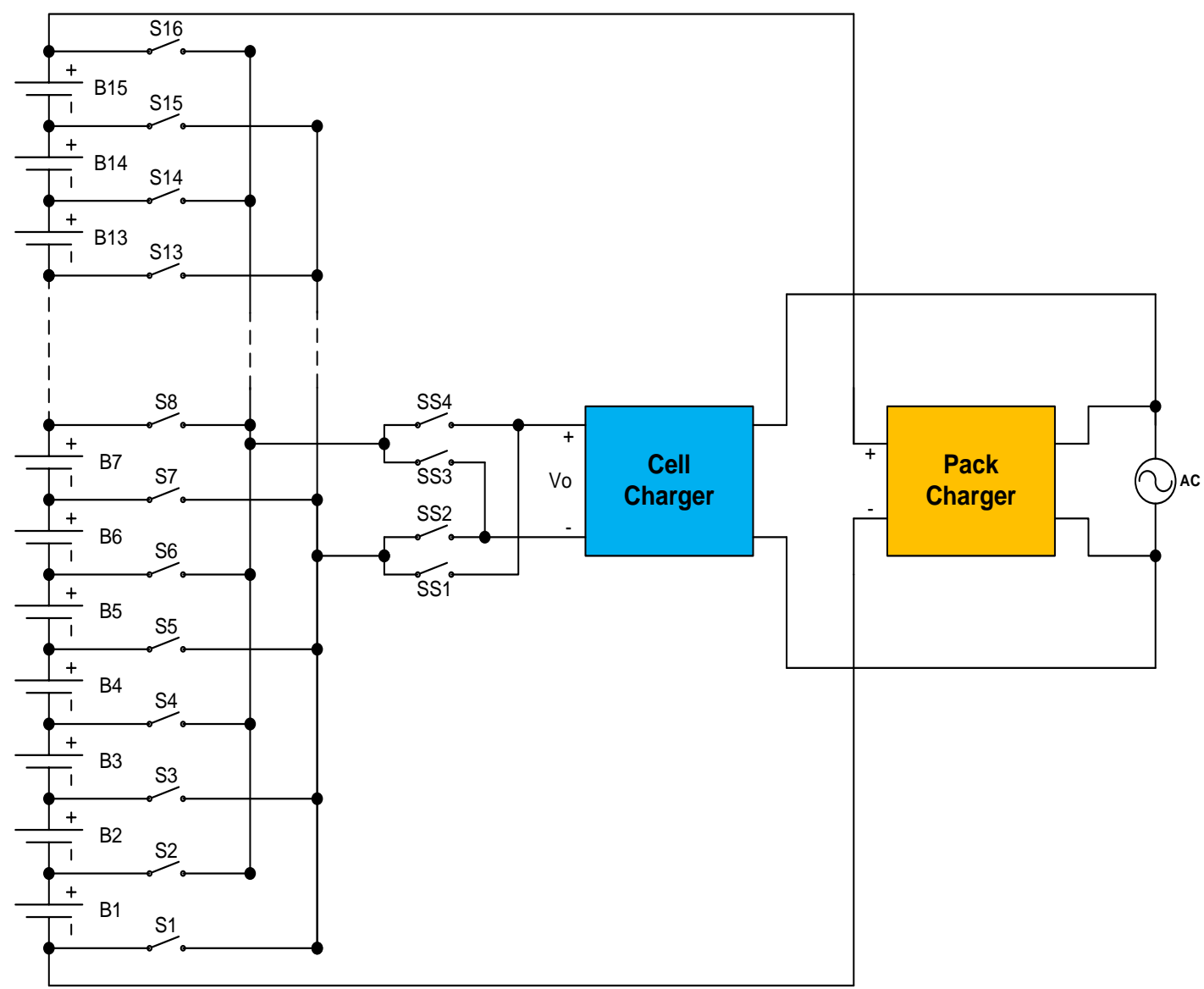

Figure 2. SSR circuit

The SSR circuit design uses 20 SSRs, namely S1-S16 and SS1-SS4 to select the voltage reading of the 15 battery cells as shown in Figure 2. If the total number of batteries in a battery pack is $n$, then the number of SSRs needed is $n+5$. Compared with the switch configuration in the previous research, the number of switches on the proposed BMS is less than the previous one which requires $2 n$ switches for $n$ batteries [29], [31]. As shown in Figure 2, each battery cell will be monitored using four SSRs with a certain configuration, which means that only four SSRs are closed simultaneously. For example, to read the voltage of the battery 1 (B1), the S1, S2, SS2, and SS4 will be closed. The SSR configuration is also used to select cells to be balanced by the cell charger in the cell balancing process. The complete SSR configuration details for reading/balancing each battery cell are shown in Table 1. 
Table 1. Switch status in the SSR circuit

\begin{tabular}{|c|c|c|c|c|c|c|c|c|c|c|c|c|c|c|c|c|c|c|c|c|}
\hline Battery & S1 & S2 & S3 & S4 & S5 & S6 & S7 & S8 & S9 & S10 & S11 & S12 & S13 & S14 & S15 & S16 & SS1 & SS2 & SS3 & SS4 \\
\hline B1 & ON & ON & & & & & & & & & & & & & & & & ON & & ON \\
\hline B2 & & ON & ON & & & & & & & & & & & & & & ON & & ON & \\
\hline B3 & & & ON & ON & & & & & & & & & & & & & & ON & & ON \\
\hline B4 & & & & ON & ON & & & & & & & & & & & & ON & & ON & \\
\hline B5 & & & & & ON & ON & & & & & & & & & & & & ON & & ON \\
\hline B6 & & & & & & ON & ON & & & & & & & & & & ON & & ON & \\
\hline B7 & & & & & & & ON & ON & & & & & & & & & & ON & & ON \\
\hline B8 & & & & & & & & ON & ON & & & & & & & & ON & & ON & \\
\hline B9 & & & & & & & & & ON & ON & & & & & & & & ON & & ON \\
\hline B10 & & & & & & & & & & ON & ON & & & & & & ON & & ON & \\
\hline B11 & & & & & & & & & & & ON & ON & & & & & & ON & & ON \\
\hline B12 & & & & & & & & & & & & ON & ON & & & & ON & & ON & \\
\hline B13 & & & & & & & & & & & & & ON & ON & & & & ON & & ON \\
\hline B14 & & & & & & & & & & & & & & ON & ON & & ON & & ON & \\
\hline B15 & & & & & & & & & & & & & & & ON & ON & & $\mathrm{ON}$ & & ON \\
\hline
\end{tabular}

\subsection{Cell charger}

Battery charging is performed using a different charging method according to the battery chemistry used. In lithium batteries, the charging process has strict requirements that must be met to ensure the safe condition of the battery. For $\mathrm{LiFePO}_{4}$ batteries, the constant current-constant voltage (CC-CV) charging method is mostly used due to its simplicity. In this paper, the CC-CV method is used to prevent overcharging of the $\mathrm{LiFePO}_{4}$ battery. The $\mathrm{LiFePO}_{4}$ battery requires $\mathrm{CC}$ to charge the battery until it reaches the specified maximum charging voltage limit for further charging with $\mathrm{CV}$ starts. The charging voltage will be kept at the maximum voltage, and in an instant, the charging current decreases significantly to avoid the battery from overcharging. The battery charging process will end when the charging current reaches a predetermined low current. In this proposed BMS, the cell charger used has a maximum current and voltage of $3 \mathrm{~A}$ and $3.65 \mathrm{~V}$, respectively.

\section{BALANCING CONTROL STRATEGY}

The proposed BMS control algorithm is illustrated in Figure 3. The basic concept of this BMS algorithm is that the voltage of each cell will be monitored by the ATtiny $45 \mathrm{~V}$ microcontroller in turn using the SSR associated with the cell. If the voltage of each cell is abnormal $\left(\mathrm{V}_{\text {cell }}\left\langle\mathrm{V}_{\min }\right.\right.$ and $\left.\mathrm{V}_{\text {cell }}>\mathrm{V}_{\max }\right)$ then the main microcontroller will give a warning in the form of a buzzer, but if all cell voltages are normal $\left(\mathrm{V}_{\min }<\mathrm{V}_{\text {cell }}<\mathrm{V}_{\max }\right)$ then the main microcontroller will determine the maximum cell voltage and activate the SSR associated with these cells. If the maximum voltage of the cell is less than $3.5 \mathrm{~V}$, the main microcontroller will send an enable signal and the amount of current issued by the pack charger to start the initial charging process. This process will take place until the maximum cell voltage more than $3.5 \mathrm{~V}$ to initiate the final charging process. Before starting this final charging process, the main microcontroller will determine the highest cell voltage again. The last highest cell voltage will remain monitored until it reaches $3.6 \mathrm{~V}$. If the cell has reached $3.6 \mathrm{~V}$, the cell balancing process will begin. The process of balancing the cell starts with balancing cell-1 for 1 minute, then balancing cell- 2 for 1 minute and so on until cell-15. This balancing process is carried out if all cell voltages have not reached $3.6 \mathrm{~V}$ and the difference between the maximum and minimum cell voltage reaches $15 \mathrm{mV}$. The cell balancing process uses a cell charger to charge/balance each cell alternately through the SSR associated with the cell. The overall flowchart of this algorithm is presented in Figure 3.

\section{RESULTS AND DISCUSSION}

In this proposed BMS test, a 15S1P $200 \mathrm{Ah} \mathrm{LiFePO}_{4}$ battery pack was used [33]. Figure 4 depicts the experimental apparatus to test the BMS prototype, which consists of battery pack, pack charger, DC1894B module, and the BMS prototype. The battery pack is formed by 15 cells of $3.2 \mathrm{~V}, 200$ Ah battery connected in series which produce a nominal voltage and store energy of $48 \mathrm{~V}$ and $9.6 \mathrm{kWh}$, respectively. This battery pack is usually used for special purpose electric vehicles such as golf cars or the like. To charge the battery pack, a charger is used with a maximum voltage and current of $55 \mathrm{~V}$ and $25 \mathrm{~A}$. The DC1894B module from Analog Devices was used to measure the voltage of these 15 cells and will communicate with a PC to store the measurement results. The initial and final voltages of each cell measured by the DC1894B module are shown in Table 2. In Table 2, the difference in cell voltage between the uppermost and lowermost voltages at the start of the charging process is $8.6 \mathrm{mV}$. After the battery pack is charged and enters the final charging process, the difference in cell voltage between the uppermost and lowermost voltages reaches 145.1 
$\mathrm{mV}$. In the final balancing process, the difference in cell voltage between the highest and the lowest voltage is $15.1 \mathrm{mV}$. The experimental test results of the BMS prototype are presented in Figure 5.

As depicted in Figure 5 (a) and (b), the proposed BMS can be used to balance cells that have a lower voltage than other cells. In this test, the time needed to balance the 15 cells reaches 6 hours from the difference between the highest and lowest cell voltages of $145.1 \mathrm{mV}$ to $15.1 \mathrm{mV}$. In terms of balancing time, this result is better than previous research which took 6 hours to balance 13 batteries with a capacity of 10 Ah from the difference between the highest and lowest voltages of $460 \mathrm{mV}$ to $336 \mathrm{mV}$ [32]. In addition, in this research, the difference between the highest and lowest voltages at the end of the balancing process is only $15.1 \mathrm{mV}$ compared to $336 \mathrm{mV}$ in the previous research.

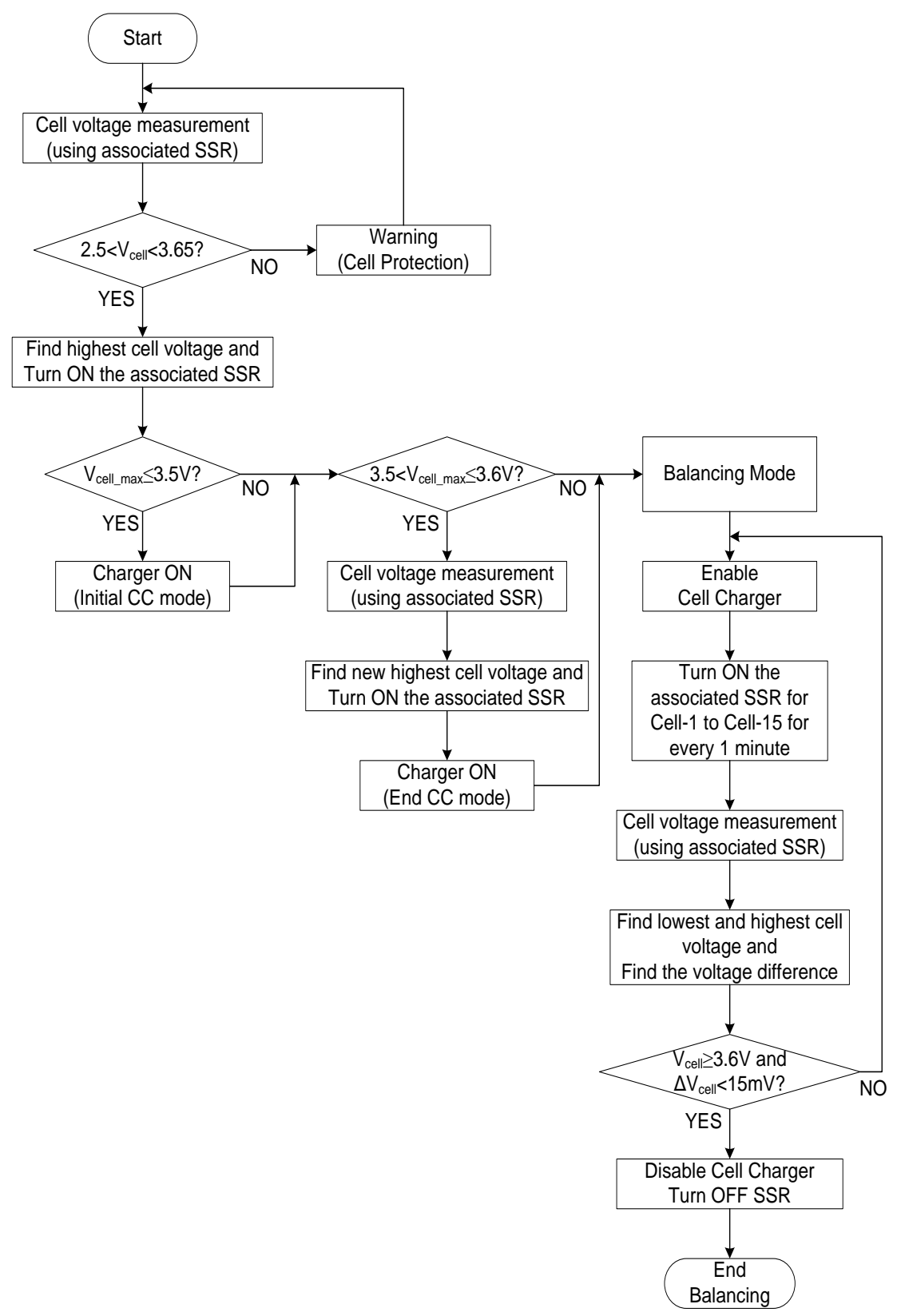

Figure 3. The proposed BMS control algorithm 


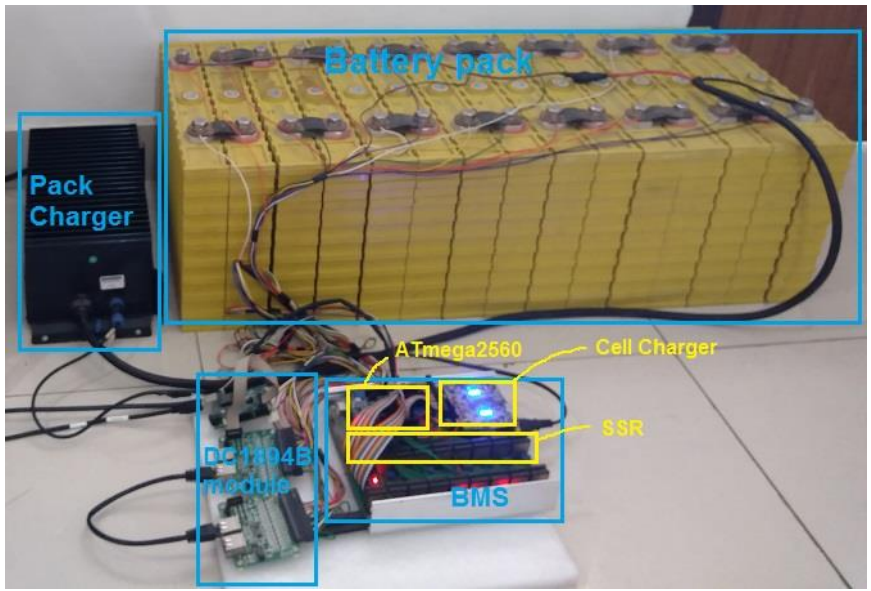

Figure 4. Experimental test
Table 2. Cell voltage at the beginning of the charging process and the end of the balancing process

\begin{tabular}{ccc}
\hline Battery & Initial Voltage $(\mathrm{V})$ & Final Voltage $(\mathrm{V})$ \\
\hline Cell-1 & 3.3264 & 3.6005 \\
Cell-2 & 3.3309 & 3.599 \\
Cell-3 & 3.3297 & 3.5967 \\
Cell-4 & 3.329 & 3.5965 \\
Cell-5 & 3.3309 & 3.5979 \\
Cell-6 & 3.3277 & 3.596 \\
Cell-7 & 3.3305 & 3.5982 \\
Cell-8 & 3.3266 & 3.5954 \\
Cell-9 & 3.3279 & 3.5855 \\
Cell-10 & 3.3314 & 3.5901 \\
Cell-11 & 3.3283 & 3.5914 \\
Cell-12 & 3.3305 & 3.592 \\
Cell-13 & 3.3291 & 3.5967 \\
Cell-14 & 3.335 & 3.5957 \\
Cell-15 & 3.3301 & 3.6006 \\
\hline
\end{tabular}

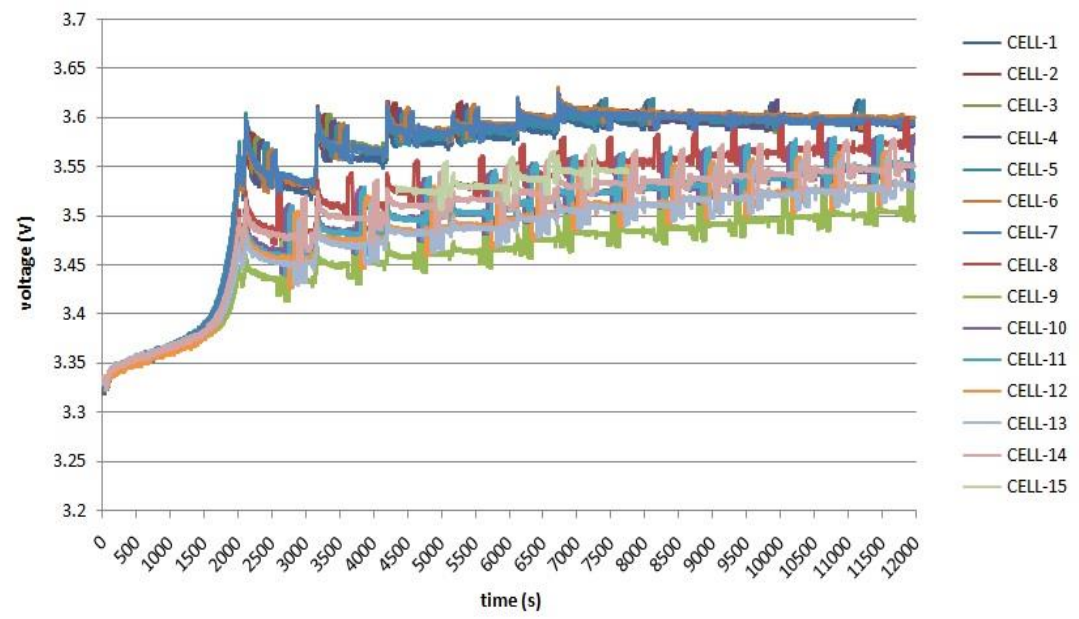

(a)

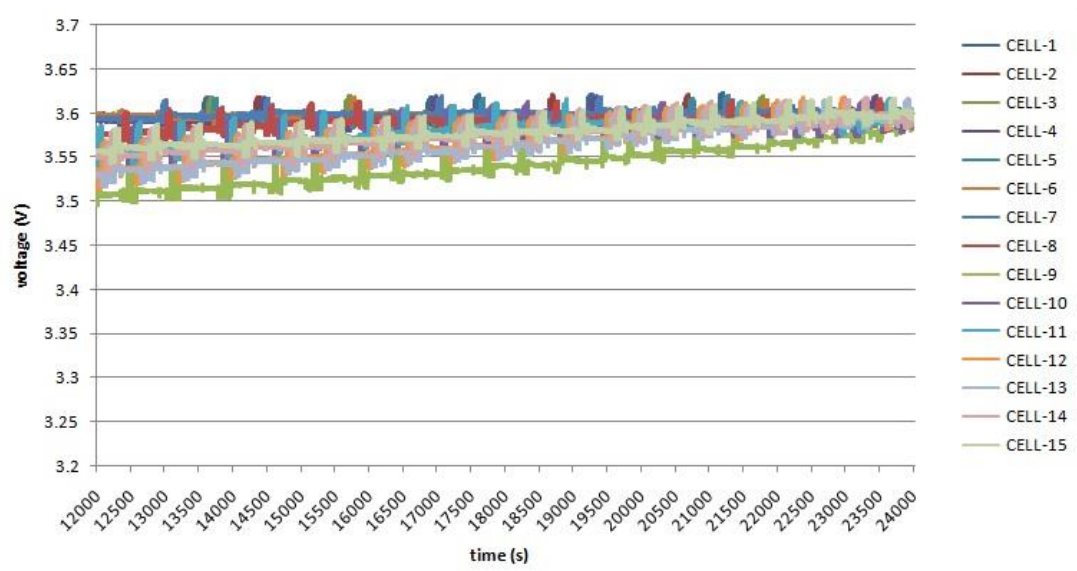

(b)

Figure 5. Measurement of the voltage for each cell on the battery pack, (a) under initial charging, (b) at the end of balancing process

\section{CONCLUSION}

The proposed BMS prototype with the cell charger concept accompanied by a reduction in the number of switches can be used to balance the cell voltages of $15 \mathrm{LiFePO}_{4} 200 \mathrm{Ah}$ batteries connected in 
series. The number of switches needed to balance $n$ cells is only $n+5$ switches compared to the previous research which requires $2 n$. Reducing this number of switches is very useful for battery packs with at least six cells. The balancing process of 15 batteries was carried out alternately by utilizing SSR with certain configurations to balance each $\mathrm{LiFePO}_{4}$ cell in the battery pack. The test results show that the time required to equalize 15 cells reaches 6 hours from the difference between the highest and lowest cell voltages of 145.1 $\mathrm{mV}$ to $15.1 \mathrm{mV}$. The duration of this balancing process is mainly influenced by the large capacity of the cell used for experiments. In general, this balancing time is significantly influenced by the cell capacity, the number of unbalanced cells, and also the difference between the lowest and the highest cell voltage.

\section{REFERENCES}

[1] Z. B. Omariba, et al., "Review of Battery Cell Balancing Methodologies for Optimizing Battery Pack Performance in Electric Vehicles," IEEE Access, vol. 7, pp. 129335-129352, 2019.

[2] M. Brandl, et al., "Batteries and battery management systems for electric vehicles," in 2012 Design, Automation \& Test in Europe Conference \& Exhibition (DATE), pp. 971-976, 2012.

[3] Amin, et al., "Implementation of a LiFePO4 battery charger for cell balancing application," J. Mechatronics, Electr. Power, Veh. Technol., vol. 9, no. 2, pp. 81-88, 2018.

[4] Amin, et al., "Passive balancing battery management system using MOSFET internal resistance as balancing resistor," 2017 Int. Conf. Sustain. Energy Eng. Appl., pp. 151-155, 2017.

[5] Y. Yuanmao, et al., "Zero-Current Switching Switched-Capacitor Zero-Voltage-Gap Automatic Equalization System for Series Battery String," IEEE Trans. Power Electron., vol. 27, no. 7, pp. 3234-3242, 2012.

[6] M. Daowd, et al., "Single switched capacitor battery balancing system enhancements," Energies, vol. 6, no. 4, pp. 2149-2174, 2013.

[7] Y. Shang, et al., "A switched-coupling-capacitor equalizer for series-connected battery strings," IEEE Trans. Power Electron., vol. 32, no. 10, pp. 7694-7706, 2017.

[8] F. S. Azad, et al., "Active cell balancing of Li-Ion batteries using single capacitor and single LC series resonant circuit," Bulletin of Electrical Engineering and Informatics, vol. 9, no. 4, pp. 1318-1325, 2020.

[9] S. Li, et al., "A high efficiency active battery balancing circuit using multi-winding transformer," IEEE Trans. Ind. Appl., vol. 49, no. 1, pp. 198-207, 2013.

[10] H. Dai, et al., "A novel dual-inductor based charge equalizer for traction battery cells of electric vehicles," Electr. Power Energy Syst., vol. 67, pp. 627-638, 2015.

[11] Y. Chen, et al., "A multiwinding transformer cell-to-cell active equalization method for Lithium-Ion batteries with reduced number of driving circuits," IEEE Trans. Power Electron., vol. 31, no. 7, pp. 4916-4929, 2016.

[12] Z. Xinxin, et al., "Active vehicle battery equalization scheme in the condition of constant-voltage / current charging and discharging," IEEE Trans. Veh. Technol., vol. 66, no. 5, pp. 3714-3723, 2017.

[13] K. Lee, et al., "Active balancing of Li-ion battery cells using transformer as energy carrier," IEEE Trans. Ind. Electron., vol. 64, no. 2, pp. 1251-1257, 2017.

[14] X. Cao, et al., "Multi-layer modular balancing strategy for individual cells in a battery pack," IEEE Trans. Energy Convers., vol. 33, no. 2, pp. 526-536, 2018.

[15] M. Einhorn, et al., "Improved performance of serially connected Li-Ion batteries with active cell balancing in electric vehicles," IEEE Trans. Veh. Technol., vol. 60, no. 6, pp. 2448-2457, 2011.

[16] F. Mestrallet, et al., "Multiphase interleaved converter for lithium battery active balancing," IEEE Trans. Power Electron., vol. 29, no. 6, pp. 2874-2881, 2014.

[17] Y. Wang, et al., "A novel active equalization method for lithium-ion batteries in electric vehicles," Appl. Energy, vol. 145, pp. 36-42, 2015.

[18] J.-C. Lin, "Development of a two-staged balancing scheme for charging lithium iron cells in series," IET Electr. Syst. Transp., vol. 6, no. 3, pp. 145-152, 2016.

[19] M. Evzelman, et al., "Active Balancing System for Electric Vehicles with Incorporated Low Voltage Bus," IEEE Trans. Power Electron., vol. 31, no. 11, pp. 7887-7895, 2016.

[20] J. Gallardo-Lozano, et al., "Battery equalization active methods," J. Power Sources, vol. 246, pp. 934-949, 2014.

[21] C. Pinto, et al., "Evaluation of advanced control for Li-ion battery balancing systems using convex optimization," IEEE Trans. Sustain. Energy, vol. 7, no. 4, pp. 1703-1717, 2016.

[22] F. Feng, et al., "A review of equalization strategies for series battery packs: variables, objectives, and algorithms," Renew. Sustain. Energy Rev., vol. 116, pp. 1-18, 2019.

[23] M. M. Hoque, et al., "Battery charge equalization controller in electric vehicle applications: A review," Renew. Sustain. Energy Rev., vol. 75, pp. 1363-1385, 2017.

[24] J. Carter, et al., "Cell equalisation circuits: A review," J. Power Sources, vol. 448, pp. 1-10, 2020.

[25] M. Caspar, et al., "Systematic comparison of active balancing: A model-based quantitative analysis," IEEE Trans. Veh. Technol., vol. 67, no. 2, pp. 920-934, 2018.

[26] G. Kirbiš, et al., "High performance autonomous charge equalization in series connected batteries," IEEE Trans. Aerosp. Electron. Syst., vol. 55, no. 1, pp. 95-107, 2019.

[27] A. Tavakoli, et al., "Control and analysis of a modular bridge for battery cell voltage balancing," IEEE Trans. Power Electron., vol. 33, no. 11, pp. 9722-9733, 2018.

[28] T. Duraisamy and D. Kaliyaperumal, "Active cell balancing for electric vehicle battery management system," International Journal of Power Electronics and Drive System (IJPEDS), vol. 11, no. 2, pp. 571-579, 2020. 
[29] C. Duan, et al., "A solar power assisted battery balancing system for electric vehicles," IEEE Trans. Transp. Electrif., vol. 4, no. 2, pp. 432-443, 2018.

[30] M. Preindl, "A battery balancing auxiliary power module with predictive control for electrified transportation," IEEE Trans. Ind. Electron., vol. 65, no. 8, pp. 6552-6559, 2018.

[31] H. Zhang, et al., "Active battery equalization method based on redundant battery for electric vehicles," IEEE Trans. Veh. Technol., vol. 68, no. 8, pp. 7531-7543, 2019.

[32] Soeprapto, et al., "Battery management system on electric bike using lithium-ion 18650," International Journal of Power Electronics and Drive System (IJPEDS), vol. 10, no. 3, pp. 1529-1537, 2019.

[33] Amin, et al., "Discharge test to detect unbalancing in electric vehicle LiFePO4 battery pack," in 2019 International Conference on Sustainable Energy Engineering and Application (ICSEEA), pp. 21-25, 2019.

\section{BIOGRAPHIES OF AUTHORS}
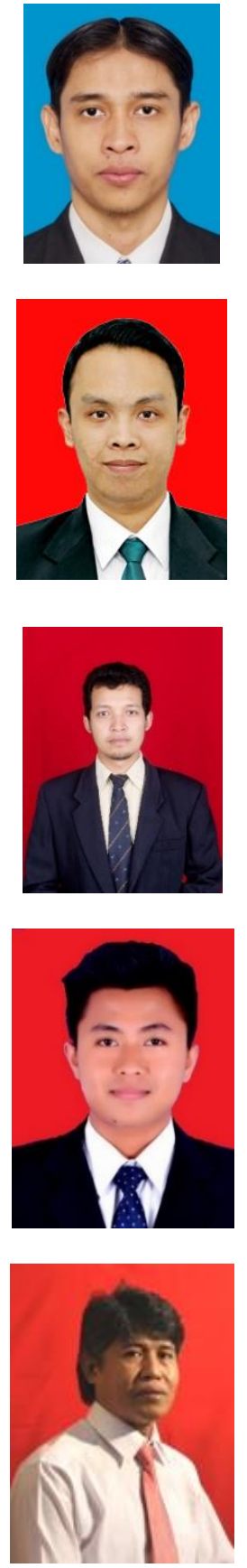

Amin was born in Tegal, Central Java, Indonesia, in 1982. He graduated from Jenderal Achmad Yani University in Bandung, Indonesia before joining the Indonesian Institute of Science (LIPI) as junior researcher in 2008. He obtained his Master of Engineering degree in electrical engineering from the School of Electrical Engineering and Informatics, Institut Teknologi Bandung (ITB), Bandung, Indonesia, in 2012. His research interests are battery management system, energy management system, and dc-dc converter.

Alexander Christantho Budiman was born in Sydney Australia in 1988. He obtained his Ph.D. in mechanical engineering from the National University of Singapore in 2016. He is an alumnus of the ASEAN University Network/Southeast Asia Engineering Education Development Network (AUN/SEED-Net). He has been a visiting graduate student at the University of Western Ontario and a postdoctoral research fellow at the National Taiwan University, before joining the Indonesian Institute of Sciences (LIPI) as junior researcher in early 2019. His research interests are subsonic vortex flows, wind tunnel experiments, as well as thermal management system in electric vehicles. Dr. Budiman is a member of IEEE, HKSME, and the International Indonesian Scholars Association (I-4).

Sunarto Kaleg was born in Surabaya, Indonesia in 1981. He became a researcher at the Indonesian Institute of Science (LIPI) since 2006 after graduated from Universitas Brawijaya, Indonesia. He obtained his Master of Engineering degree from the Department of Mechanical Engineering, Universitas Sebelas Maret, Indonesia. He is actively involved in co-supervising undergraduate students in Mechanical or Electrical Engineering from various local universities in Indonesia. His research interest is in the area of electric vehicle platform and automotive lightweight materials.

Sudirja was born in Lubuk Linggau, Indonesia in 1994. He obtained his Master of Engineering degree from Universitas Indonesia in 2018. He worked in one of the state-owned enterprises of Indonesia before joining Indonesian Institute of Science (LIPI) as assistant researcher in 2019. His research interest is in lightweight materials, including their applications in vehicle chassis and body.

Abdul Hapid is a senior researcher and the head of the Electric Vehicle research group at the Research Center for Electrical Power and Mechatronics, Indonesian Institute of Sciences (LIPI). He graduated from the Department of Mechanical Engineering, Universitas Hasanuddin, Indonesia. He joined the Indonesian Institute of Science (LIPI) in 1995. For the past two decades, he led multiple national-scale research projects in electric vehicles and has produced some prototypes, including a converted gasoline-to-electric Kijang car and a minivan solely dedicated for mobile meeting purpose. His research interest is propulsion system of electric vehicles. 